\title{
建築・土木分野の検査ロボット* （建築物の検查ロボットを中心に）
}

鈴 木 昭 夫** 吉 川 一 三**

\section{1. は じめに}

建設産業に技ける自動化, ロボット化は近年各方面で 活発に種々の試みがなされるようになってきている。 こ のような技術開発のインパクト材料としては次のような 要因が考えられる.

(1) 建設業は他産業に比べて災害発生率が比較的多く, 就労者の危隃, 苦渋, 污れ作業からの解放が強く望まれ ている.

(2) 建設労働者の高令化が進んでおり, 高令者でも負 担の少ない作業環境, さらに若年層が魅力を感じるよう な作業環境をつくり出すことが望まれている.

(3) 生産性はここ10 年来横ばい状態の低迷を続けて 预り，製造業に大きく水をあけられている。

しかし，建設ロボットは工場の中で㗢く製造業のロボ ットに比べて, 人工的に整備されていない自然環境条件 への対応性, フレキシビリティな機動性, 長尺・大重 量・不定形な対象物のハンドリング性など，技術的に克 那しなければならない困難な問題を多くかかえて和り， やっとよちよち歩きを始めたばかりの状態であると言光 る.

このような状況下で，建築・土木分野における検査口 ボットもこれから本格的に始動する段階にある. 以下に まだ少数ではあるが，検査ロボットの実施例について紹 介し, 特にその中の外壁診断ロボットについて検知原理, 彰断システムの概要について解説する.

\section{2. 建築・土木分野における 検査ロボットの実施例}

建築・土木分野に批いて検査業務は, (1)事前調査, (2) 施工管理, (3)構造物拈よび設備機器のメンテテンス管理, の 3 段階に大別できる. 各段階とも検査の種類, 内容が 疝範囲かつ多岐にわたり, 今後はあらゆる産業分野での 各種計測技術の進歩と相俟って,より科学的な調査およ

原稿受付 1986 年 10 月 3 日

* Inspection Robots in Construction Works

** 竹中技術研究所

び検査管理により, 施工の品質向上，安全性，経済性な どを追求する姿勢が強まる傾向にあると思われる.

以下に, 現在建築・土木分野で実用化されている検査 ロボットの事例を紹介する.

（1）海底調査潜水ロポッ卜

本ロボットは水深 $70 \mathrm{~m}$ まで潜水でき, 海底の地形や 地盤を人間に代って自由に調査でき，橋脚の基礎工事， その他一般海洋土木工事の調査および検查作業に威力を 発揮するるのである. 本体は 4 本ずつ組になった合計 8 本の足で支えられ，それらを交互に動かすことにより海 底を移動しながらカラーテレビ撮影, スチール写真撮影 をすることができる（写真 1).

（2）クリーンルーム検査ロボット

クリーンルームは清浄度等高い品質を要求されるので, その品質, 性能を確保し, 保証するため整しい検查・測 定が必要である、検査のために無理な姿勢を強いる苦渋 作業の軽減，検査作業の省力化・信頼性の向上，作業に 伴なう発塵量の減少化などの要請で自動化が求められて いる. 本ロボットは, 電動で走行する台車と上下, 左右 に動くアームで構成され, アームの先端に取付けた検出 器で測定し, その結果は位置の情報と共に記録される. 台車の移動は，㦿または天井に設けたマークを追跡して 行なうようになって拈り，予めプログラムされた走行順 路を移動する場合とりモートコントロールにより移動す る場合の 2 つの方式が選定できる（写真 2).

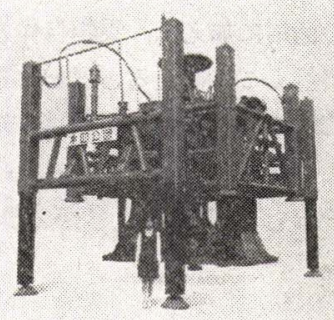

写真 1 海底調査潜水口 ボット(小松製作所)

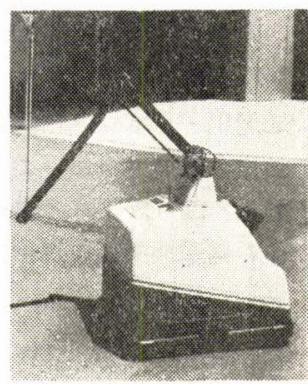

写真 2 クリーンルーム検 查ロボット(大林組) 
（3）ビル外壁診断ロボット

本ロボットは, 長年月を経た建築物の外壁材であるタ

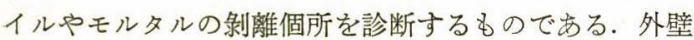
面に沿ってりモートコントロールによりロボットが移動 しながら壁面に打撃・振動を与党，センサーでその音 圧・振動数などを測定して異常值を判定することにより 剝離部を見つけ出すものである.

次にこれらビル外壁診断ロボットについて，その検 知原理, 移動機構, データ計測システムなどを解説する (写真3, 写真 4).

\section{3. ビル外壁診断ロボットの概要}

\section{（1）外壁定期診断の必要性}

コンクリート下地にタイルを張り付けたり，モルタル を塗り付けて仕上げをした建物外壁には，時に剥離故障 が発生する，これら娳離故障は，(1)材料選択，施工不良 などによる初期の接着力不足起因する初期故障と, (2) 外気の温度変化に伴って建物外壁内部に発生する応力の 繰返しによる接着力の低下に起因する劣化故障とに分け られる。これら剝離故障の発生時期は一定でなく，時に は剝離が進行し，その一部が落下して通行人に傷害を及 添すといった事故も発生する。 また, 地震時, 避難道路 面する建物の外壁から大量のタイル，モルタルが落下 するような事態が発生すれば大災害につながることも予 想される。このような事故を防止するには，定期検査を 行って剥離部を検出し, 剝離の程度に応じて適切な補

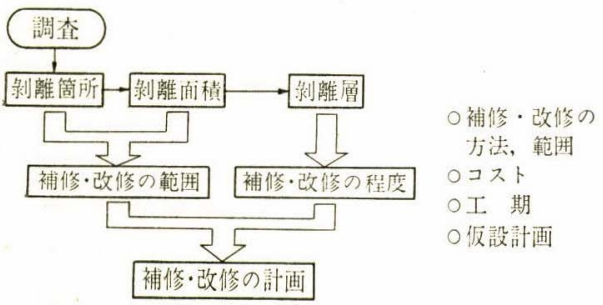

図 1 咏離調查と補修・改修計画

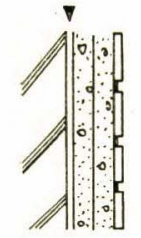

コンクリートと

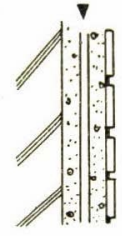

下地モルタルと

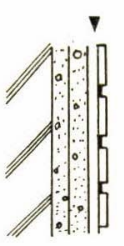

張りモルタルと 夕イル界面
図 2 タイル張壁体の㔀離層
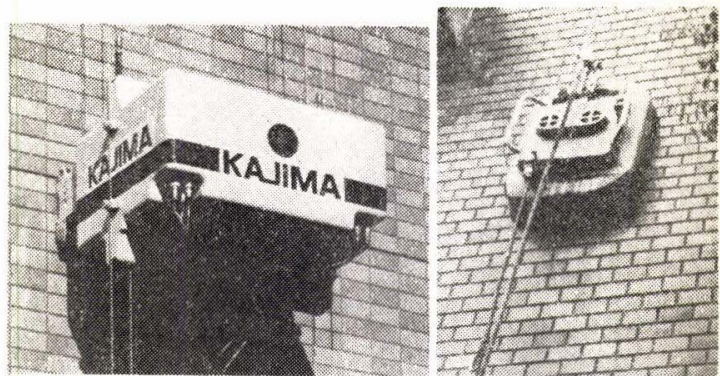

写真 3 打撃法によるビル 外壁診断ロポット （鹿島建設）
写真 4 加振法によるビル 外壁診断ロボット （竹中工務店）
修・改修対策をとることが必要である，定期検査に招い ては，外壁の剥離状沉を非破壤的に定量化することが求 められる.

従来, 外壁の剝離状況の定量化は, 人間がハンマーで 壁面をたたき，その打音を聞いて，音の違いから剝離部 を検出する官能検査法により行なわれてきた．この方法 は，人間が壁面に接近するための足場架けやゴンドラ吊 りを必要とし，かつ検查に時間がかかり，費用がかさむ ために，定期検查法として適用が難しいまたこの方法 は官能検査であるために, 時間経過に伴って判断力が低 下する．個人差が生じやすい，といった問題点を有して いる．このような問題点を解決し，簡便で信頼性の高い 非破壊検査法の開発を目的とした研究が実施されている。

（2）外壁診断で検出すべき項目

建物外壁の娳離検查時に検出すべき項目と, その結果 にもとづく補修・改修計画の流れは，図1の上うになる。 外壁診断に和いては, 剥離箇所および剥離面積の検出が 最も重要であり,この情報は, 補修・改修の程度, 緊急 度を判断する上で不可欠である.

タイル張り、モルタル塗り壁面の剝離は，いくつかあ る接着界面のうち最も接着の不十分な界面で発生する (図 2).剥離がどの接着界面で発生したかによって補

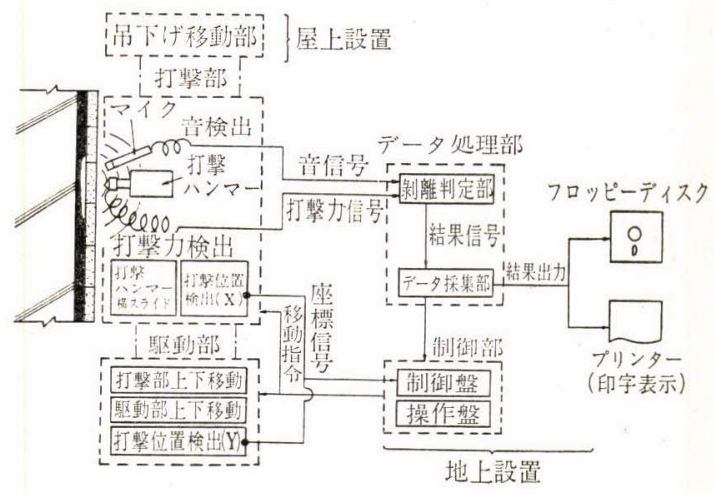

図 3 打撃法の診断システム概要 


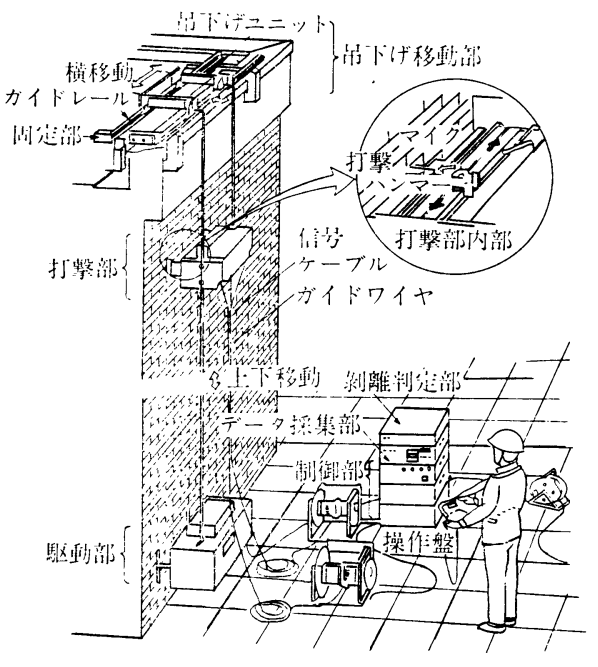

図 4 打撃法の装置概要図

修・改修方法が違ってくるので, 補修・改修計画の立 案・積算を行う際には，剝離界面を特定することが重要 になる。

（3）外壁診断法

(1) 打撃法

a) 原 理

壁面上を移動する打撃部に取り付けたハンマーで壁面 を打撃し，この時発生する打撃音圧と反発力をそれぞれ マイクロホンと打撃力検出器（荷重計）で検出する. 検 出した音圧と反発力をあらかじめ測定した健全部のそれ ぞれの基準値と比較し, 剝離判定部で判定し, 結果をア ウトプットする.

b) 診断システムの概要

診断システムの概要を図 3 に, 装置の概要を図 4 に示 $\vec{y}$

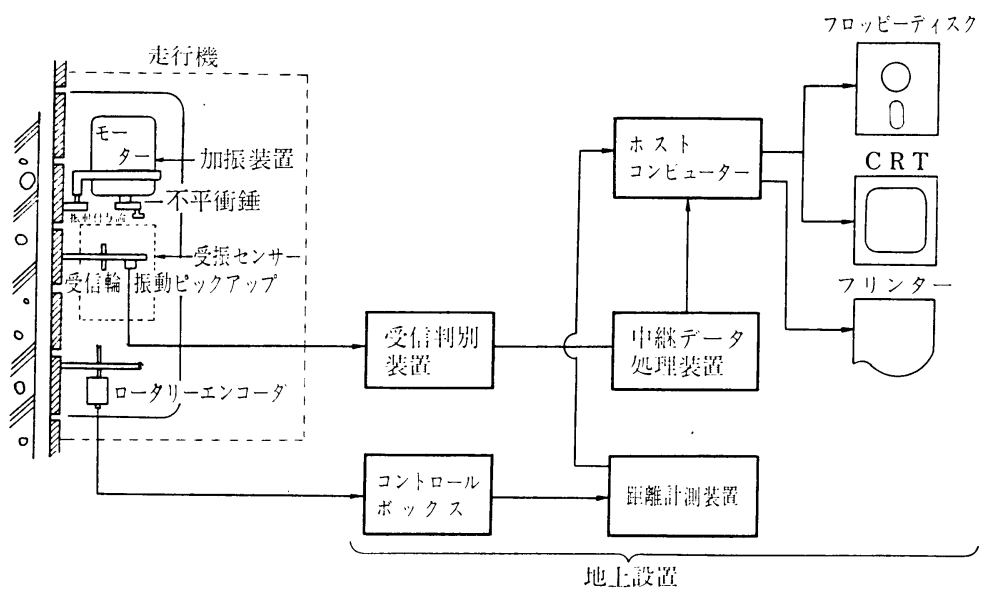

図 5 加振法の診断システム概要
吊下げ移動部……屋上パラペットに設置し，装置全体 をワイヤで吊下げ保持する.

打撃部……壁面上を移動しながら打撃を行い，打撃音 信号および打撃力信号を剥離判定部に出力する.

駆動部……エンドレスワイヤロープを駆動し，打撃部 を上下移動する。

制御部……制御盤と操作盤とから成り，駆動部・打撃 部・データ採集部に指令を与光，打撃部の $\mathrm{xy}$ 方向移動 と打撃の制御を行う.

データ処理部……剝離判定部とデータ採集部から成り, 打撃部からの打撃音と打撃力を受信して剝離判定を行い， その結果を出力する.

出力部……マイコンを使って判定結果を図面上に表示 する。

(2) 加振法

a) 原 理

壁面上を自走する走行機に取り付けた加振装置により 壁面を連続加振し，この時発生する振動を受振輪で受振 する.これを周波数分析し，特定周波数帯域での振動加 速度レベルを健全部の振動加速度レベル（あらかじめ測 定しておく）と比較し，顕著な差があった時，“剥離” と 判定する，剝離層の判定をする場合には，広周波数帯域 (31. $5 \mathrm{~Hz} \sim 8 \mathrm{kHz})$ での振動加速度レベルの分布を特 性 值とし，これを重判別分析して判定する.

b) 診断システムの概要

診断システムの概要を図 5 に，装置の概要を図 6 に示 す.

走行機……排風機で機内の排気を行いながら壁面に吸 着し，左右のキャタピラーを介して壁面上を移動する。

制御部……走行機と有線で結び，地上に設置して走行 方向・速度・加振器の回転数をコントロールする.

加振装置……加振用モーター で不平衡錘を回転して生じた振 動を振動付与輪を介して壁面に 伝え，壁面に連続 振 動を与兄 る.

検出部……壁面に接触する受 振輪を介して受けた振動を振動 ピックアップにより電気信号に 変換し，この信号をプリアンプ で増幅して，判別装置に送る. 判別装置……検出部から送ら れた信号を周波数分析し，剝離 判定を行い，その結果を出力す る. 

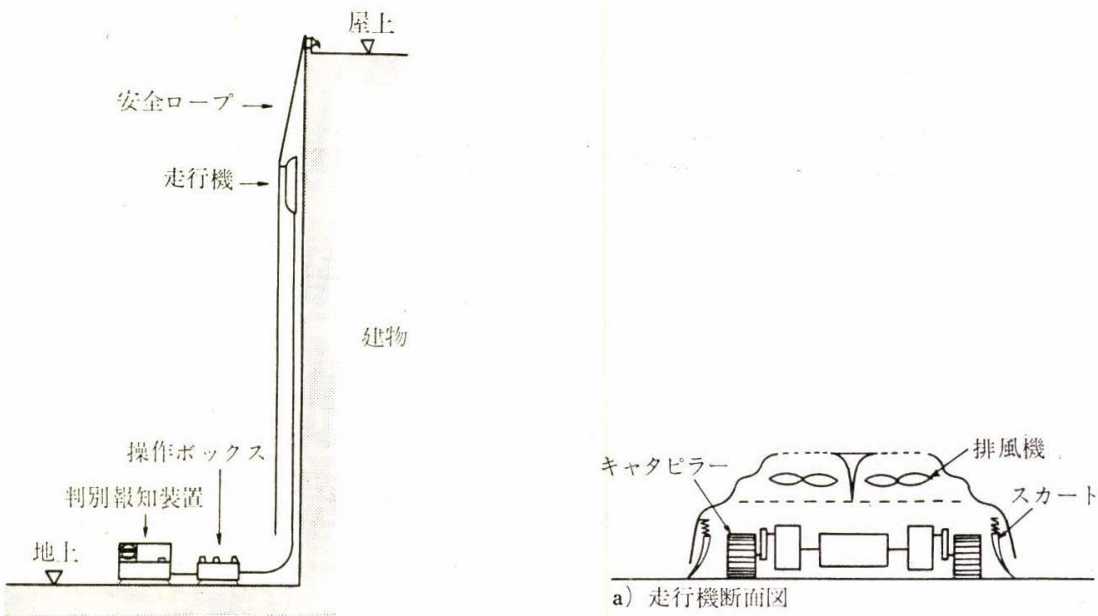

函 6 加振法の装置概要図

\section{4.おわりに}

今度の建設技術に扮いては, 大深度の地下・海洋構造 物あるいは宇宙空間構造物などの建設のように，人間が 容易に近づくことができない環境条件の中で，より先端 的で困難な技術への挑戦が要求される一方, それとは対 称的に, 既に構築された構造物のメンテナンスおよびリ フォームなどに対して，迅速かつ経済的に対応できる技 術の要求も增大するものと思われる.

このように広範囲の内容を含む建設技術の機能を効果 的に発揮するためには, 調查, 検查関連の技術は必要不 可欠のものであり, 建筑・土木分野における検査ロボッ 卜の需要は今後各方面で増々大きくなるものと推察され る.また，さらに検査機能と施工・補修機能とを合せ持 ったロボットの出現なども今後の方向として大いに考光

\section{られるところである.}

今後は, 屋外作業用としてのロボット技術の進歩と各 種産業分野に打けるセンサー関連技術の進歩との複合化 により，知能化された建設ロボットが大きく実用面で飛 躍することを期待したい。

最後に，本報をまとめるに当り，関傒者の方々から貴 重な資料を御提供頂いたことに対し，厚く扰礼申し上け゚ る次第である.

\section{参考文献}

山田：インパルスレスポソス方式によるタイル剝離検知システ ム，施工，第 244 号 (1986)，pp. 95〜97.

吉川: 連続加振 ・振動測定方式による剥離検知器の概要, リフ オーム，第 1 巻，第 6 号 (1984), pp. 27 34, pp. 39 石野: 水中ロボット RECUS, 自動化技術, 第 13 巻, 第 1 号 (1981), pp. $84 \sim 87$

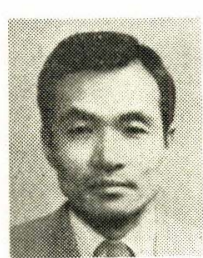

\section{鈴木昭夫 (Akio SUZUKI)}

昭和 41 年 3 月早稲田大学理工学部機械 工学科卒業, 昭和 41 年 4 月株式会社竹中 工務店入社, 機械化施工技術の研究開発に 従事, 現在に至る. 主任研究員, 日本機 械学会会員:

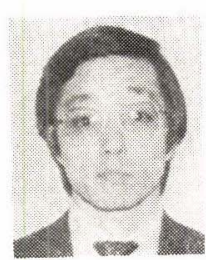

\section{吉川一三}

(Kazumi YOSHIKAWA)

昭和 44 年早稲田大学大学院建設工学修 士課程修了。同年株 式会社竹中工務店入 社, 現在に至る。日本建築学会会員 